Discussion Paper No. 04-39

\title{
Explaining Reform Deadlocks
}

Friedrich Heinemann

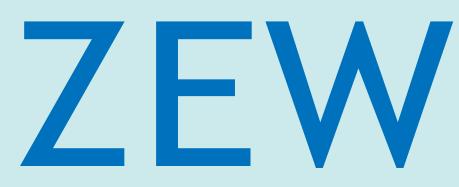

Zentrum für Europäische Wirtschaftsforschung $\mathrm{GmbH}$

Centre for European

Economic Research 
Discussion Paper No. 04-39

\title{
Explaining Reform Deadlocks
}

\author{
Friedrich Heinemann
}

Download this ZEW Discussion Paper from our ftp server:

\section{ftp://ftp.zew.de/pub/zew-docs/dp/dp0439.pdf}

Die Discussion Papers dienen einer möglichst schnellen Verbreitung von neueren Forschungsarbeiten des ZEW. Die Beiträge liegen in alleiniger Verantwortung der Autoren und stellen nicht notwendigerweise die Meinung des ZEW dar.

Discussion Papers are intended to make results of ZEW research promptly available to other economists in order to encourage discussion and suggestions for revisions. The authors are solely responsible for the contents which do not necessarily represent the opinion of the ZEW. 


\section{Non-Technical Summary}

While the reasons for poor growth rates and high unemployment tend to be well known in today's unsuccessful economies these problems are often only slowly addressed (if at all). These reform deadlocks cannot be explained easily since they cause substantial costs for large groups in the economy. This paper is a first and unique attempt to identify the factors that tend to favour or block beneficial economic reforms on a large empirical basis: the reform experience of 123 countries from different income classes since 1970.

In the preparatory theoretical part, two fundamentally different classes of explanations are discussed: those that stick to the rationality assumption and those that allow for limited rationality. Rational explanations are related to uncertainty, distributive consequences associated with reforms and the theory of interest groups. It is argued that this class of rational stories can explain important but not all dimensions of reform resistance. In addition, phenomena of rational ignorance and limited rationality must be considered for a full understanding. It is shown that behavioural anomalies as they have been established in the analysis of financial market behaviour ("behavioural finance") should have even wider applications in the economic policy context.

The empirical approach makes use of the Fraser Institute's Economic Freedom of the World (EFW) index. Due to its availability for a large country sample (123 countries) and the fact that its data range back to 1970, the EFW indicator offers a good starting point for a quantification of economic reform processes. The availability of sub-indices (e.g. with regard to the "size of government" or "regulation" or "sound money") is of particular interest in the context of economic reform obstacles. It allows to test for the impact of potential obstacles on different fields of economic reforms. A further advantage is the fact that a wide literature has established at least a correlation if not a causal relationship between economic freedom as measured by the indicator and economic growth. Measuring reform processes on the basis of the EFW indicator therefore implies the measurement of structural changes conducive for growth.

In the analysis, a reform event is defined as a significant change in the EFW index within a five year interval. In a first descriptive step, an extensive comparison shows which significant differences exist between reform and no-reform countries prior to the reform period. In the next and more refined analytical step, a probit model is estimated. The probability of reforms is explained by variables that serve as proxies for the objective need of reforms, political-economic obstacles and phenomena of limited rationality and/or rational ignorance.

A number of interesting insights emerge from this empirical analysis: The worse a country's initial institutional setting the more likely are reforms. Equally, a poor growth performance has a positive impact on a country's ability to overcome reform resistance. Among political-economic proxies the age structure has a certain 
explanatory power at least in the regressions based on the EFW total indicator. Here, reform probabilities decrease with the age of a population. This is a worrying result given the demographic future of industrial countries and the resulting needs for reforming the social systems. Data availability does not allow to test for the relevance of limited information and limited rationality in an extensive way. School enrolment as the related proxy is significant only in the government reform regression. This means a higher level of education makes it easier to reform the government sector. Apart from these results, other interesting insights emerge as a by-product: The significant period dummies are evidence for changing fashions in the focus of reforms. 


\title{
Explaining Reform Deadlocks
}

\author{
Friedrich Heinemann \\ Centre for European Economic Research (ZEW)
}

May 2004

Forthcoming: Applied Economics Quarterly

\begin{abstract}
Countries are often slow to adjust their economic structures to new necessities although this reform reluctance is costly in terms of growth and employment. This paper analyses the relevant factors that block or foster economic reforms. Theoretical considerations show that there are at least three classes of potentially relevant factors: the objective need for reforms, political-economic issues and factors associated with limited rationality or rational ignorance. In the empirical analysis, a reform event is quantified as a significant change of the Economic Freedom of the World indicator within a five-year-period. This allows to run probit estimations for a large country panel starting in the 1970s where the probability of reform is explained by a number of proxies covering all three classes of potential factors. The results suggest that the initial extent of economic freedom and growth performance are empirically relevant factors. Furthermore, countries with an ageing population appear to behave less reform friendly.
\end{abstract}

Acknowledgement: The author gratefully acknowledges helpful comments from Mathias Erlei (Technische Universität Clausthal) und Martin Schüler (ZEW).

JEL-Classification: E 63, H00

Keywords: economic policy reforms, economic freedom, reform resistance, limited rationality

P.O. Box 103443

68034 Mannheim

Germany
Phone +496211235149

Fax +496211235223

Email_heinemann@zew.de 


\section{Introduction}

Why are countries frequently so slow to adjust their economic structures to new necessities although this reform reluctance leads to substantial growth and employment losses? In these days it is of crucial importance to find a convincing answer to this question.

Particularly, in big EU countries like Germany, France and Italy there appear to be huge lags between identification of economic problems and the implementation of political remedies. Examples concern highly regulated labour markets, an excessive tax burden and the exploding costs of the social security systems not adjusted to the needs of an ageing population. That these factors are at the root of growth problems in many countries is largely uncontroversial in spite of all debates in detail. Given this principal consensus it is hard to explain why a number of countries are so hesitant to change structures even if the costs of the reform deadlock have become highly visible in the growth and labour market statistics.

This phenomenon is not only a challenge for economic policy but also for economic theory: It is no easy task to reconcile this self-destructive behaviour of whole societies with the central economic assumption of rationality. Of course, politicaleconomic theory possesses concepts and models to explain under certain assumptions "stupid" social decision making in spite of individual rationality. Explanations as shortly surveyed below range from Down's notion of "rational ignorance" to Alesina's and Dranzen's "war of attrition". However, this class of elegant explanations loses its convincing power, the more visible, relevant and certain the costs of the reform deadlock become for an overwhelming majority of the population.

In some instances, the refusal to acknowledge basic economic realities appears so widely spread among populations that it is not easy to stick faithfully to the assumption that voters are rational and optimising individuals. The debate on the pension age is one of the examples: With the dramatic increase in life expectancy, low birth rates and the resulting population ageing there is no doubt that the lifting of the pension age is one of the unavoidable measures to limit the exploding dependency ratios in the coming decades. Nevertheless overwhelming majorities of all age classes in the population are opposed to this measure according to recent opinion polls, e.g., in Germany.

In financial economics behavioural economists have made use of non-rational psychological patterns in human behaviour to explain financial market phenomena. It is amazing that the same instruments have rarely been applied to the analysis of economic policy. Of course, it is a challenge for the economic profession to debate the rationality assumption. However, given the fact that irrationalities are observable in financial market decision making there is no reason to exclude the possibility of irrational behaviour a priori as an explanation for economic policy failures. 
Given these profound intellectual and political problems, our understanding for the true reasons behind today's reform deadlocks is absolutely dissatisfactory. These research deficiencies are particularly marked on the empirical field as Rodrik (1996, 25) complains: "We now need theoretically informed case studies - or more formal tests - that attempt to discriminate among these alternative stories". This study follows this recommendation not in regard to case study techniques but focuses on more formal testing on the basis of a large country panel. With the exception of Pitilik and Wirth (2003) to our knowledge there are no comparable attempts in the literature. Close to our approach, these authors endogenise economic reforms but focus on the hypothesis that crisis is a precondition for reforms without showing interest into a wide spectre of rational and irrational types of reform obstacles.

This paper's empirical approach is the following: Based on a panel of 123 countries it is analysed which factors can explain that some countries experience significant reform eras and others do not. The occurrence of reforms is measured on the basis of Fraser Institute's Economic Freedom of the World (EFW) index. Both the aggregate index and the sub-components are analysed so that differentiated insights for different fields of economic policy (size of government, property rights, monetary regime, external freedom and regulation) can be derived. Among the potentially explaining factors a distinction is made between three classes of variables: first, proxies for the objective necessity of reform, second, proxies for political-economic reform obstacles and third, proxies that hint to the relevance limited information or limited rationality.

The structure is as follows: In the next section a brief survey is given on the classes of reform obstacles that are discussed in the literature. Section three describes the variables and presents a first descriptive view on the data. In section four, the econometric analysis is presented. Conclusions are drawn in the final section.

\section{Reform obstacles}

Explanations why societies do not accept economic reforms that are beneficial for a large majority of citizens can be divided into those that stick to the rationality assumption and those that do not.

\section{Explanations based on rational reform resistance}

Examples for rational explanations are the following (for a survey see Rodrik, 1996): Reforms might be beneficial to the population as a whole in the sense of higher growth rates and welfare, nevertheless distributive consequences are unavoidable. There are always groups that suffer from adjusting economic structures. The standard interest group explanation related to these distributive aspects is that minorities that suffer from reforms are well organised and powerful enough to block any change hurting them. The distributive consequences might 
interact with discount rates differing between groups in society. If certain reform projects have a J-curve effect - short-run losses followed by long-term gains groups with a short time horizon and high discount rates are likely to oppose these projects. These inter-temporal aspects are likely to be of particular relevance in ageing societies where the growing higher age segments of the population apply a heavy discounting.

Uncertainty about a reform's outcome - possibly coupled with risk-aversion - can be a further obstacle to reforms: Fernandez and Rodrik (1991) show that even with risk-neutral voters uncertainty about the winners' identity can lead to the democratic rejection of reforms that are beneficial for a majority. Models that focus on incomplete information and coordination problems show that reforms might be blocked even though this implies that the politically powerful groups hurts themselves. Alesina's and Drazen's "war of attrition” (1991) is the classic example on this field where two groups are uncertain about the opponent's cost of stabilisation and both have an incentive to delay reforms. These examples for rational reform resistance can be relevant under democratic regimes or under dictatorship alike.

Rational ignorance (Downs, 1957) is a further variant of rational explanations for detrimental institutional stickiness. According to the Downsian notion voters' individual information optimisation results in socially inefficient information activities. The consequence is that voters are badly informed about the consequences of reform options and about the costs of the status quo.

While these rational explanations are elegant and without doubt hint towards important real dimensions of the reform problem they do not appear to be fully satisfactory. So it is not clear at all why reforms should necessarily increase uncertainty about the economic future of individuals or certain interest groups. This is particularly questionable if the status quo is not sustainable. With an ageing population, sticking to the status quo, e.g., in the field of pay-as-you-go pension systems creates significant uncertainty about future pension payments. In this field, reforms that create a more sustainable system are likely to be conducive for the pension promise's credibility. Therefore, reforms can be a way to limit uncertainty.

Neither are those explanations always convincing which are based on the distributive consequences of reforms. Nowadays countries in acute reform deadlocks suffer from significant growth and welfare losses which hurt both a large majority of the population and many politically powerful interest groups. Here it is hard to see which groups are reform losers and at the same time powerful enough to block reforms against all those who would benefit. Interest group related explanations also face the difficulty to explain why opposing minorities which are politically influential cannot be compensated by reform winners. The incentive for paying these compensations is the larger on the side of the winners the higher the costs of the status quo. 
Finally it is doubtful whether rational ignorance can really establish a systematic bias against reforms. A low level of information means that people have wrong expectations about the consequences of reforms but there is no obvious argument why this should necessarily imply any bias against reforms. Without further arguments it is equally likely that poor information is associated with an overly euphoric assessment of reforms (Wittman, 1995). In any case the rational ignorance arguments is weakened the more visible the cost of institutional stickiness become.

\section{Explanations based on limited rationality}

Given the above mentioned difficulties of rational explanations a fundamentally different class of approaches gives up the assumption of full rationality. Proponents (Caplan, 2001) state their analytical starting point in the following way: "[Voters] oppose better policies not from complicated strategic calculations, but because they don't understand what works. ... . What dominates political debate and public opinion is not subtle strategizing, but elementary economic misconception.”

Behavioural patterns that constitute deviations from rationally optimising behaviour have frequently been applied in financial market economics (see for example Daniel, Hirshleifer and Teoh, 2002). It is amazing that the success of the "behavioural finance" field is not yet paralleled by a field like "behavioural economic policy". Compared to financial markets, human instincts and psychologically rooted irrationalities should have a deeper impact in economic policy phenomena due to lacking market forces which punish irrationalities on an individual basis. Compared to an instinct driven voter, a voter who practices rational optimisation at the ballot box does not benefit from better politics. From an individual perspective, irrational voting is extremely cheap; the marginal costs are basically zero. This is different for private economic decision, e.g., in regard to investment, labour market and education decisions. Choosing an education without job and income chances, for example, is punished on an individual basis and thus demands a high individual price. Choosing a political programme at the ballot box which is doomed to economic failure is individually costless.

In addition, Heinemann (2001) argues that a number of empirically proven psychological anomalies have a substantial explanatory potential in the context of reform resistance. Examples are phenomena such as the "status quo bias", the "endowment effect" and "loss aversion". The status quo bias describes a situation where people have a preference for one option among many others only because this option happens to be the status quo (Samuelson and Zeckhauser, 1988). If a change occurs this specific option loses attraction immediately. The endowment effect stands for preferences that depend on whether a certain good is possessed or not: Experiments show that the willingness to pay for acquiring good $\mathrm{x}$ is significantly smaller than the price the same person would accept for giving up good $\mathrm{x}$ (Kahneman et al., 1991). Loss aversion, finally, denotes the fact that the absolute 
change in utility associated with a loss is larger than the absolute change in utility associated with a gain (Tversky and Kahnemann, 1991). With loss aversion the utility function is non-continuous in the reference point which tends to be the status quo. All these anomalies work against reforms that change the status quo. Sometimes these anomalies also underline arguments familiar from rational explanations: Loss aversion, for example, might explain why the reform resistance of reform losers is more intense than the reform support from reform winners.

Empirically it is hard to disentangle rational ignorance from rational irrationality since both phenomena are deeply interrelated within the human mind. However, both concepts hint to the same proxies that can be included in empirical studies, for example variables on the state of a population's education.

This short overview demonstrates that there is a whole universe of factors which might be potentially relevant for the explanation of reform speed. There is no single empirical approach which would be able to cover all these dimensions. Hence, in the following we apply a less ambitious approach. We look for empirical evidence for the relevance of three classes of factors:

- First, factors which represent the objective need of reforms and thus correspond to rational explanations in the sense that increasing costs of institutional stickiness should help overcome reform resistance.

- Second, political-economic factors which explain the relative power of reform-resisting groups and thus correspond to rational explanations linked to distributional consequences of reforms.

- Third, factors which correspond to rational ignorance and/or limited rationality - both classes of explanations can hardly be disentangled on the basis of the macro-approach applied here.

\section{Variables and descriptive analysis}

Any attempt to study the economics of reform processes by statistical and econometric tools faces a serious data problem. Adjusting an economy's structure to new requirements is a complex process whose quantification is no straightforward task. The problems are manifold: It must be decided which kind of institutional change is a relevant and appropriate change and which not. Furthermore, changes must be translated into numbers that offer a starting point for the empirical assessment. Finally, the quantification should be available for different countries and different time periods in order to make inter-country comparisons and analyses along the time axis.

In coping with these problems this study bases its quantification of reform processes on the Economic Freedom of the World (EFW) index developed by the Fraser Institute (Gwartney and Lawson, 2003a,b). The content of the index has developed 
over time. It is available since 1970 in intervals of five years and covers 123 countries. In its current version it contains 38 variables among which 18 variables are obtained from survey data while the others are based on objectively quantifiable data. ${ }^{1}$ The variables are grouped into the following five major areas for which individual sub-indices are calculated: size of government, legal system and property rights, sound money, freedom to exchange with foreigners and regulation of credit, labour and business. After experimenting with different weighting approaches, in its recent version Gwartney and Lawson (2003b) calculate the aggregate index simply as unweighted mean of its five sub-components. For each variable economic freedom is measured on a scale of 0 to 10 where $0 / 10$ means that a country is completely unfree/free

Although necessarily there are many debatable issues in the context of such an ambitious indicator, the EFW indicator offers a good starting point for a quantification of economic reform processes. Its availability for a large country sample since 1970 makes it preferable to the Heritage Foundation's index of economic freedom (O’Driscoll et al., 2003) which only covers the years since 1995. The availability of sub-indices is of particular interest in the context of economic reform obstacles. It allows testing for the impact of potential obstacles on different fields of economic reforms. A further big advantage is the fact that a wide literature has established at least a correlation if not a causal relationship between the indicator and economic growth (for a survey, see de Haan, 2003). Measuring reform processes on this basis therefore implies the measurement of structural changes conducive for growth.

For the analysis a reform event is defined as a "significant" change in the EFW index within a five year interval where "significant" stands for an increase of 0.5 , 0.75 or 1 index point. The focus on the binary variable (reform yes or no) corresponds to the nature of reform blockades in which a sweeping reform breakthrough is needed associated with a wide and significant adjustment of outdated structures.

Figure 1 and Tables 1-2 describe some characteristics of the reform history since the seventies: Reform activities started to accelerate in the eighties and reached a peak in the 1990-1995 period. This peak period was also characterised by particularly ambitious projects with a large share of "big" reforms (increase in EFW indicator by at least one point) in total reform events. Over time a marked shift in reform priorities has occurred: During the 70s and 80s the reform focus was on freedom of exchange, legal system/property rights and stable money. The size of government has become a major reform issue only since the second half of the eighties. Regulation has been addressed even later starting with the peak reform period 1990/95. Reform history differs among income groups: Low income countries

1 Survey data come from the International Country Risk Guide and the World Economic Forum's Global Competitiveness Report. 
experienced a delay in following the global reform trend with rising numbers of reform events only since 1990/95. Reform frequency in high income countries peaked relatively early in 1985/90.

Figure 1: Frequency of reform events (in \% of period observations)

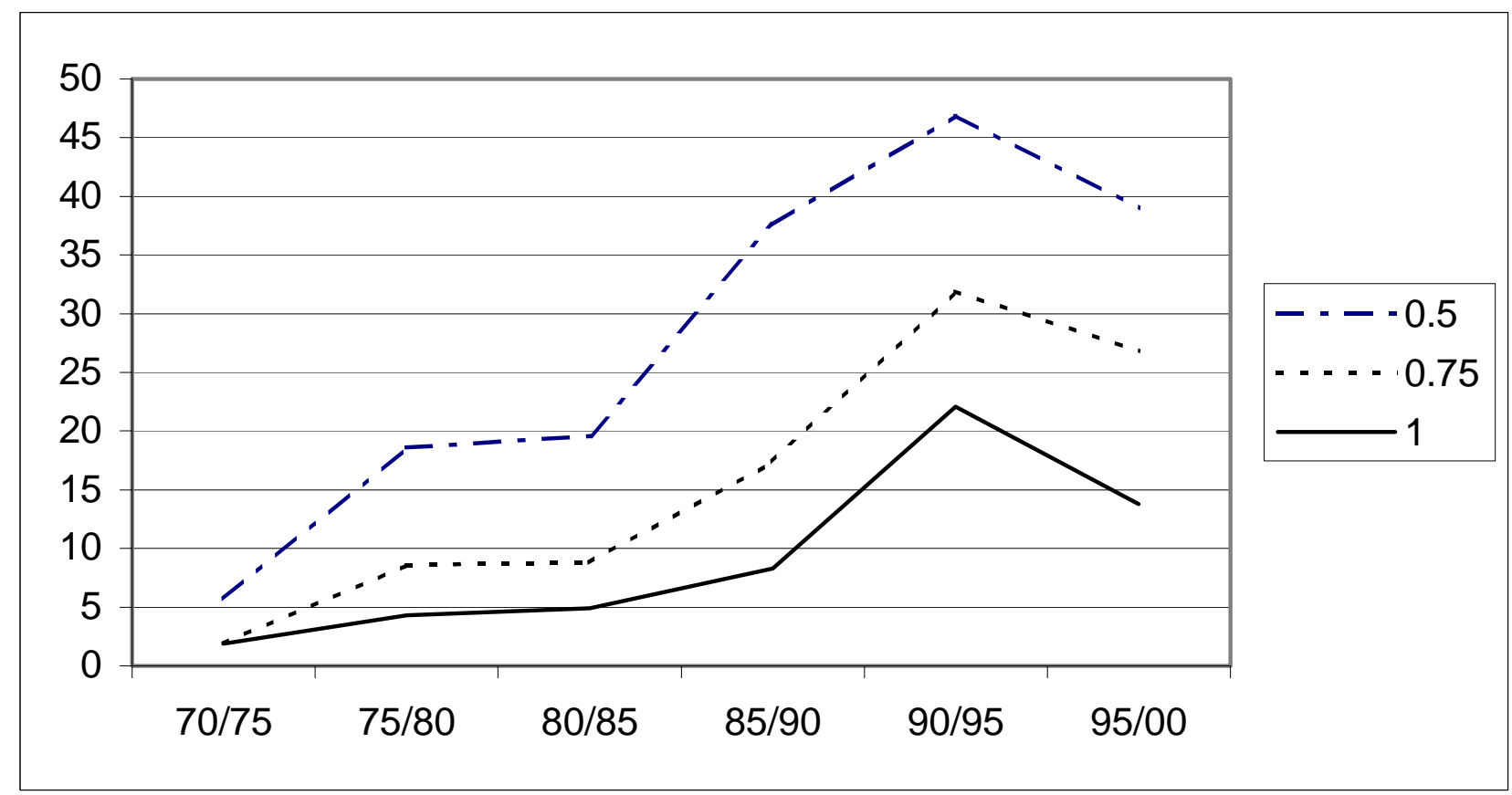

A reform event is defined as a change in the EFW aggregate indicator by at least 0.5/0.75/1.0 points. 
Table 1: Frequency of reform events (EFW sub-indicators): in \% of period observations (total number of period observations)

\begin{tabular}{|c|c|c|c|c|c|c|c|c|}
\hline & \multicolumn{7}{|c|}{ period } \\
\hline & & $70 / 75$ & $75 / 80$ & $80 / 85$ & $85 / 90$ & $90 / 95$ & $95 / 00$ & $\begin{array}{c}\text { all } \\
\text { period } \\
\mathrm{s}\end{array}$ \\
\hline \multirow{3}{*}{$\begin{array}{l}\text { change of } \\
\text { at least } 0.5\end{array}$} & government & $\begin{array}{l}15.6 \\
(96)\end{array}$ & $\begin{array}{r}13.1 \\
(107)\end{array}$ & $\begin{array}{c}23.4 \\
(111)\end{array}$ & $\begin{array}{r}46.5 \\
(114)\end{array}$ & $\begin{array}{r}42.1 \\
(114)\end{array}$ & $\begin{array}{c}33.6 \\
(122)\end{array}$ & $\begin{array}{c}29.7 \\
(664)\end{array}$ \\
\hline & legal system & $\begin{array}{l}10.0 \\
(50)\end{array}$ & $\begin{array}{l}70.0 \\
(50)\end{array}$ & $\begin{array}{l}27.8 \\
(90)\end{array}$ & $\begin{array}{c}27.3 \\
(110)\end{array}$ & $\begin{array}{c}47.7 \\
(111)\end{array}$ & $\begin{array}{l}22.0 \\
(123)\end{array}$ & $\begin{array}{r}32.8 \\
(534)\end{array}$ \\
\hline & Money & $\begin{array}{c}11.2 \\
(107)\end{array}$ & $\begin{array}{c}30.4 \\
(112)\end{array}$ & $\begin{array}{c}46.4 \\
(112)\end{array}$ & $\begin{array}{c}27.6 \\
(116)\end{array}$ & $\begin{array}{l}38.0 \\
(121)\end{array}$ & $\begin{array}{l}55.3 \\
(123)\end{array}$ & $\begin{array}{r}35.3 \\
(691)\end{array}$ \\
\hline \multirow[t]{2}{*}{ index } & Exchange & $\begin{array}{l}39.7 \\
(73)\end{array}$ & $\begin{array}{l}21.3 \\
(94)\end{array}$ & $\begin{array}{r}22.5 \\
(102)\end{array}$ & $\begin{array}{r}28.6 \\
(105)\end{array}$ & $\begin{array}{r}50.0 \\
(106)\end{array}$ & $\begin{array}{l}29.9 \\
(117)\end{array}$ & $\begin{array}{r}31.8 \\
\text { (597) }\end{array}$ \\
\hline & Regulation & $\begin{array}{l}15.6 \\
(45)\end{array}$ & $\begin{array}{l}9.6 \\
(73)\end{array}$ & $\begin{array}{c}9.8 \\
(102)\end{array}$ & $\begin{array}{c}10.4 \\
(106)\end{array}$ & $\begin{array}{l}41.5 \\
(118)\end{array}$ & $\begin{array}{r}26.8 \\
(123)\end{array}$ & $\begin{array}{r}20.6 \\
(567)\end{array}$ \\
\hline
\end{tabular}

Table 2: Frequency of reform events for country income groups (EFW indicator): in \% of period observations (total number of period observations)

\begin{tabular}{|c|c|c|c|c|c|c|c|c|}
\hline & \multicolumn{7}{|c|}{ period } \\
\hline & & $70 / 75$ & $75 / 80$ & $80 / 85$ & $85 / 90$ & $90 / 95$ & $95 / 00$ & $\begin{array}{c}\text { all } \\
\text { period } \\
\mathrm{s}\end{array}$ \\
\hline \multirow[b]{2}{*}{ change of } & high income & 0.0 & 17.9 & 20.0 & 60.0 & 30.0 & 19.4 & 25.1 \\
\hline & countries & (26) & (28) & (30) & (30) & (30) & (31) & (175) \\
\hline \multirow{2}{*}{ at least } & upper middle & 0.0 & 38.5 & 20.0 & 36.4 & 54.5 & 42.3 & 35.7 \\
\hline & $\begin{array}{c}\text { income } \\
\text { countries }\end{array}$ & (9) & (13) & (20) & (22) & (22) & (26) & (112) \\
\hline $0.5 \mathrm{in}$ & lower middle & 18.2 & 6.7 & 20.8 & 40.7 & 72.4 & 42.4 & 38.8 \\
\hline EFW & $\begin{array}{l}\text { income } \\
\text { countries }\end{array}$ & (11) & (15) & (24) & (27) & (29) & (33) & (139) \\
\hline \multirow[t]{2}{*}{ index } & low income & 14.3 & 14.3 & 17.9 & 13.3 & 34.4 & 51.5 & 27.8 \\
\hline & countries & (7) & (14) & (28) & (30) & (32) & (33) & (144) \\
\hline
\end{tabular}

World Bank income classifications 
As explained in our theoretical considerations in section 2 there are at least three classes of variables being potentially helpful for explaining the occurrence of reforms: first, variables representing the objective need for reforms; second, variables that are proxies for relevant political-economic factors; and third, variables that could be related to phenomena of rational ignorance and irrationality. The specific selection of variables in the following is influenced by data availability whereby extensive use has been made of the World Bank's World Development Indicator (WDI) data base (see appendix for variable definitions and sources). The WDI data have the advantage to cover the time span and country sample of the Fraser Institute's economic freedom indicator and thus can be integrated into the analysis.

\section{Proxies for need of reforms:}

Relevant variables to be included in this class are unemployment and growth - the latter defined as growth of total GDP or GDP per capita. In line with the hypothesis that a crisis is helpful to overcome reform blockades, changes in growth and unemployment rates should be more relevant than levels.

Variables describing a country's openness like export ratios and the extent of capital flows should also play a role since they indicate the intensity of present external competitive pressure. The same holds for the change of the real effective exchange rate which signals the development of external competitiveness. Sometimes the size of a country in terms of its population is also interpreted as a proxy for external competition in the sense that a small country should suffer from losing competitiveness faster than a big country.

Moreover, a natural proxy for the economic need of reforms is the starting value of the economic freedom indicator: The closer the distance to the maximum value of 10 the lower the need for reform activities in the logic of this study's approach.

\section{Proxies for political-economic reform resistance}

Variables in the WDI data set that may be used as political-economic proxies are mainly those related to the population's age structure. As argued in section 2 an important element of rational reform resistance is related to the discounting of future reform benefits. This discounting is likely to increase with age. A variable such as population share above 65 should, therefore, be negatively linked with reform capability. Similarly, a negative link can be expected in regard to dependency ratios. A positive link should exist between reform capability and life expectation: The longer the individual time horizon the more attractive are reforms associated with $\mathrm{J}$ curve effects.

Other variables that would be useful, such as indicators of inequality, are not available for a reasonable number of observations. 


\section{Proxies for rational ignorance and/or limited rationality}

Reform resistance associated with rational ignorance or innate irrationalities should be a negative function of the population's level of economic education. People knowledgeable about the economic system should also be more competent judges over appropriate reforms at the ballot box. Even though they have no direct incentive to get informed or to judge in a rational way a high level of economic education should - as a by-product - lead to better informed and more rational voting decisions. Unfortunately, there is no internationally consistent data set on economic education. Therefore, variables describing the general state of education such as school enrolment ratios have to be used. It is also experimented with WDI data quantifying the availability of media information (newspapers, televisions) although it is not clear whether these very general media indicators are really a good indicator for a country's quality of media information. A more direct proxy for the population's economic education are variables quantifying the development of the financial sector such as credit aggregates - the presumption here is that a country's financial development and the population's economic knowledge is correlated.

Table 3 presents the relevant variables' means separately for reform and no-reform countries together with the results of the t-test for a difference in means. The variables are measured prior to the reform/no-reform period (for details of calculation, see appendix) in order to avoid an impact of reversed causality (e.g. from reform activity to growth).

Reform countries, initially to reform period, have the following significant (at least $10 \%$ significance for t-test) differences compared to no-reform countries: lower economic freedom, lower growth, and smaller increase in p.c. income (PPS) in preceding years.

Many other differences - though not statistically significant - show expected signs. Reform countries, compared to no-reform countries are characterised by a larger growth reduction, a smaller p.c. income (PPS), a higher unemployment rate, a larger increase in unemployment rate, a larger real appreciation of the exchange rate, smaller dependency ratios, a longer life expectation, a smaller share of population below 65 and higher school enrolment ratios (tertiary schooling). 
Table 3: Test for differences in mean for reform/no reform events (number of observations in brackets)

\begin{tabular}{|c|c|c|c|}
\hline & \multicolumn{2}{|c|}{ reform (EFW increase of at least 0.5 ) } & \multirow[b]{2}{*}{ significance t-test } \\
\hline & $\begin{array}{l}\text { means prior to } \\
\text { reform period }\end{array}$ & $\begin{array}{l}\text { means prior to no- } \\
\text { reform period }\end{array}$ & \\
\hline \multicolumn{4}{|c|}{ proxies reform needs } \\
\hline $\begin{array}{l}\text { Start value EFW } \\
\text { indicator }\end{array}$ & $4.98(178)$ & $5.66(392)$ & 0.000 \\
\hline growth rate & $2.82(176)$ & $3.87(376)$ & 0.000 \\
\hline change in growth rate & $-0.92(171)$ & $-0.53(366)$ & 0.292 \\
\hline GDP p.c. (PPS) & $5703.35(171)$ & $6359.91(328)$ & 0.227 \\
\hline $\begin{array}{l}\text { change in GDP p.c. } \\
\text { (PPS) }\end{array}$ & $1.26(153)$ & $1.35(270)$ & 0.001 \\
\hline unemployment rate & $8.73(94)$ & 7.65 (135) & 0.173 \\
\hline $\begin{array}{l}\text { change in unemployment } \\
\text { rate }\end{array}$ & $1.39(63)$ & $0.64(91)$ & 0.209 \\
\hline $\begin{array}{l}\text { change in real effective } \\
\text { exchange rate }\end{array}$ & $0.99(80)$ & $0.95(142)$ & 0.448 \\
\hline $\begin{array}{l}\text { private capital flows in } \\
\% \text { GDP }\end{array}$ & $11.37(158)$ & $16.02(294)$ & 0.130 \\
\hline exports/GDP & $31.95(176)$ & $34.12(372)$ & 0.319 \\
\hline Size of population & $41.51(177)$ & $37.95(387)$ & 0.748 \\
\hline \multicolumn{4}{|c|}{ proxies demographics related reform resistance } \\
\hline dependency ratio & $0.71(177)$ & $0.74(387)$ & 0.150 \\
\hline life expectation & $65.24(177)$ & $63.85(387)$ & 0.131 \\
\hline population share $>=65$ & $6.32(177)$ & $6.60(387)$ & 0.466 \\
\hline \multicolumn{4}{|c|}{ proxies rational ignorance / limited rationality } \\
\hline $\begin{array}{l}\text { Daily newspapers per } \\
1,000 \text { people }\end{array}$ & $122.44(170)$ & $135.91(377)$ & 0.329 \\
\hline TV-sets per 1,000 people & $171.89(174)$ & $183.33(367)$ & 0.464 \\
\hline $\begin{array}{l}\text { School enrolment ration } \\
\text { (tertiary education) }\end{array}$ & $16.00(168)$ & $15.13(369)$ & 0.501 \\
\hline $\begin{array}{l}\text { Domestic bank credit in } \\
\text { \% GDP }\end{array}$ & $52.35(172)$ & $54.86(374)$ & 0.488 \\
\hline
\end{tabular}


Variables with a "wrong" and insignificant sign are: capital flows, export ratios, number of newspapers and televisions and bank credit to the private sector. Population size is not significantly different between reform and no-reform countries.

Overall, the proxies for the need of reforms (in particular, the growth variables) perform best in this simple testing. Important proxies for political-economic reform resistance (like age structure and dependency ratio) and for limited rationality/information (school enrolment) show the correct sign but lack significance. However, this kind of descriptive exercise must now be substantiated by a more refined multivariate analysis.

\section{Econometric analysis}

The next step of the analysis is to explain the occurrence of reform event in the framework of a probit model. The binary $1 / 0$ variable reform/no-reform is now modelled to be jointly determined by a whole range of explanatory variables which according to our theory - could have an impact on the probability of reform. In order to avoid difficulties with reversed causation, explanatory variables are measured prior to the five-year-window which is the basis for the observation of a reform event. Generally, the estimations include time and income group dummies in order to control for significant differences in reform behaviour across income groups and periods.

Compared to section 3, data availability leads to exclusion of a number of variables from the regressions: unemployment ratio, GDP p.c. and real exchange rates. Furthermore, a number of variables turned out to be insignificant and have, therefore, been excluded from the presented regressions: dependency ratio, relative number of newspapers and TV-sets, size of population, bank credit to the private sector.

Nevertheless, proxies of each of the groups "reform needs", "rational resistance” and "limited information/rationality" survive and contribute to the explanation at least of certain aspects in the determination of reforms. 
Table 4: $\quad$ Probit regression: reform determinants, EFW total indicator

\begin{tabular}{|c|c|c|c|}
\hline \multirow[b]{2}{*}{$\begin{array}{l}\text { independent } \\
\text { variables }\end{array}$} & \multicolumn{3}{|c|}{$\begin{array}{c}\text { dependent variable: reform event yes (1) /no (0) } \\
\text { periods: 70/75 - 95/00 }\end{array}$} \\
\hline & 0.5 & 0.75 & 1 \\
\hline constant & $1.306(0.24)$ & $0.765(0.55)$ & $3.256^{* * *}(0.03)$ \\
\hline dummy 75/80 & $0.251(0.49)$ & $0.383(0.49)$ & $-0.078(0.90)$ \\
\hline dummy 80/85 & $0.427(0.22)$ & $0.606(0.26)$ & $0.198(0.73)$ \\
\hline dummy 95/90 & $1.116 * * *(0.00)$ & $0.931 *(0.08)$ & $0.474(0.40)$ \\
\hline dummy 90/95 & $1.553 * * *(0.00)$ & $1.667 * * *(0.00)$ & $1.429 * *(0.01)$ \\
\hline dummy 95/00 & $1.585 * * *(0.00)$ & $1.794 * * *(0.00)$ & $1.309 * *(0.02)$ \\
\hline $\begin{array}{l}\text { dummy upper } \\
\text { middle income }\end{array}$ & $-0.572 * *(0.03)$ & $-0.276(0.34)$ & $-0.539(0.12)$ \\
\hline $\begin{array}{l}\text { dummy lower } \\
\text { middle income }\end{array}$ & $-0.852 * * *(0.00)$ & $-0.737 * *(0.03)$ & $-1.167 * * *(0.00)$ \\
\hline dummy low income & $-1.264 * * *(0.00)$ & $-1.092 * *(0.03)$ & $-2.052 * * *(0.00)$ \\
\hline Start value EFW & $-0.661^{* * *}(0.00)$ & $-0.630 * * *(0.00)$ & $-0.769 * * *(0.00)$ \\
\hline growth & $-0.015(0.49)$ & $-0.065 * *(0.01)$ & $-0.080 * * *(0.01)$ \\
\hline export-GDP-ratio & $0.001(0.73$ & $0.001(0.72)$ & $0.008 *(0.06)$ \\
\hline life expectation & $0.027 *(0.08)$ & $0.025(0.15)$ & $-0.002(0.90)$ \\
\hline $\begin{array}{l}\text { population share } \\
>65\end{array}$ & $-0.053 *(0.05)$ & $-0.053 *(0.09)$ & $-0.039(0.28)$ \\
\hline school enrolment & $-0.001(0.84)$ & $-0.008(0.37)$ & $-0.006(0.59)$ \\
\hline obs. & 519 & 519 & 519 \\
\hline reform obs. & 166 & 98 & 57 \\
\hline R2 (Mc Fadden) & 0.21 & 0.25 & 0.30 \\
\hline
\end{tabular}

p values in parentheses, */**/***: significant at $10 \% / 5 \% / 1 \%$. 
With regard to the overall reform activity (reform event defined as significant change of aggregate EFW indicator, Table 4) the following results emerge: A number of period and income group dummies are highly significant. Period dummies hint to a particularly reform friendly mood since 1990/95. Ceteris paribus, high income countries are significantly more reform friendly than lower middle and low income countries. Economic growth rates and the start value of economic freedom have a significant impact and support the view that economic necessity is a relevant driving force for reforms. Economic openness measured by the export ratio has the correct sign in the sense that larger openness increases the pressure for reform but reaches 10 percent significance only in the regression for substantial reform events (change of EFW indicator of at least 1 point). Age structure as proxy for rational reform-resistance of population groups with heavy discounting turns out to be weakly significant. The same holds for life expectation, although only in one specification. In contrast to that, school enrolment as a proxy for limited rationality is insignificant in all three specifications. Thus, the regressions for overall reform indicators do not hint to the relevance of limited rationality.

This picture changes considerably when different reform fields are analysed separately on the basis of the five EFW sub-indicators (Table 5). First of all, income group dummies lose significance - income levels do not seem to affect reform probabilities when the approach differentiates between reform fields. Time dummies, however, remain significant and repeat the message of Table 1 that the focus of reforms shifts over time: There appears to be changing "fashions" of reform independently from the objective economic environment - for example the fact that cutting back government became a trend since $1985 / 90$ or that 1990/1995 were the heydays of deregulation.

Proxies for reform needs lose significance in these differentiated regressions: While the start value of the EFW indicator continues to be highly significant, the growth rate keeps its expected sign but is now insignificant for each sub-indicator. Export openness is significant with the correct sign in the context of reforms targeted at freedom of exchange which is a plausible result: The larger the shares of exports in GDP the more costly are restrictions to international transactions. Less plausible is the export ratio's significance in regard to stable money with a negative sign. 
Table 5: Probit regression: reform determinants, EFW sub-indicators

\begin{tabular}{|c|c|c|c|c|c|}
\hline \multirow[b]{2}{*}{$\begin{array}{l}\text { Independent } \\
\text { variables }\end{array}$} & \multicolumn{5}{|c|}{$\begin{array}{l}\text { dependent variable: reform event yes (1) /no (0) } \\
\text { periods: 70/75 - 95/00 } \\
\text { definition of reform event: } \\
\text { increase in EFW sub-indicator of at least 0.5: }\end{array}$} \\
\hline & government & $\begin{array}{c}\text { legal } \\
\text { structure }\end{array}$ & exchange & money & regulation \\
\hline constant & $-0.449(0.67)$ & $-0.940(0.41)$ & $1.851^{*}(0.08)$ & $1.472(0.17)$ & $0.227(0.86)$ \\
\hline dummy 75/80 & $-0.323(0.38)$ & $\begin{array}{c}1.692 * * * \\
(0.00)\end{array}$ & $0.373(0.21)$ & $\begin{array}{c}-0.581^{* *} \\
(0.04)\end{array}$ & $-0.060(0.88)$ \\
\hline dummy 80/85 & $0.373(0.24)$ & $0.656^{* *}(0.04)$ & $\begin{array}{c}0.860 * * * \\
(0.00)\end{array}$ & $\begin{array}{c}-0.714^{* * *} \\
(0.01)\end{array}$ & $-0.139(0.71)$ \\
\hline dummy 85/90 & $\begin{array}{c}0.940 * * * \\
(0.00)\end{array}$ & $0.598 *(0.07)$ & $0.503 *(0.08)$ & $\begin{array}{c}-0.546^{* *} \\
(0.05)\end{array}$ & $-0.304(0.44)$ \\
\hline dummy 90/95 & $\begin{array}{c}0.830 * * * \\
(0.01)\end{array}$ & $\begin{array}{c}1.277 * * * \\
(0.00)\end{array}$ & $\begin{array}{c}0.774 * * * \\
(0.01)\end{array}$ & $0.309(0.26)$ & $\begin{array}{c}0.982 * * * \\
(0.01)\end{array}$ \\
\hline dummy 95/00 & $0.668 * *(0.05)$ & $0.589 *(0.09)$ & $\begin{array}{c}1.376^{* * *} \\
(0.00)\end{array}$ & $-0.129(0.66)$ & $0.634 *(0.09)$ \\
\hline $\begin{array}{l}\text { dummy upper } \\
\text { middle inc. }\end{array}$ & $0.057(0.83)$ & $\begin{array}{c}-0.538^{* *} \\
(0.05)\end{array}$ & $-0.032(0.90)$ & $-0.139(0.61)$ & $-0.106(0.71)$ \\
\hline $\begin{array}{l}\text { dummy lower } \\
\text { middle inc. }\end{array}$ & $0.127(0.67)$ & $-0.322(0.29)$ & $-0.123(0.66)$ & $-0.302(0.32)$ & $-0.050(0.88)$ \\
\hline $\begin{array}{l}\text { dummy low } \\
\text { income }\end{array}$ & $0.342(0.43)$ & $-0.397(0.39)$ & $-0.512(0.23)$ & $-0.184(0.68)$ & $-0.523(0.31)$ \\
\hline start value EFW & $\begin{array}{c}-0.267 * * * \\
(0.00)\end{array}$ & $\begin{array}{c}-0.245^{* * *} \\
(0.00)\end{array}$ & $\begin{array}{c}-0.296 * * * \\
(0.00)\end{array}$ & $\begin{array}{c}-0.324 * * * \\
(0.00)\end{array}$ & $\begin{array}{c}-0.302 * * * \\
(0.00)\end{array}$ \\
\hline growth & $-0.019(0.37)$ & $0.008(0.72)$ & $-0.010(0.64)$ & $-0.007(0.74)$ & $-0.014(0.59)$ \\
\hline export-GDP-ratio & $0.004(0.17)$ & $0.003(0.33)$ & $0.006^{* *}(0.05)$ & $\begin{array}{c}-0.009 * * \\
(0.02)\end{array}$ & $0.005(0.17)$ \\
\hline life expectation & $0.009(0.55)$ & $0.017(0.27)$ & $-0.019(0.18)$ & $0.013(0.35)$ & $-0.003(0.87)$ \\
\hline $\begin{array}{l}\text { population share } \\
>65\end{array}$ & $-0.038(0.15)$ & $-0.015(0.59)$ & $-0.006(0.83)$ & $-0.053 *(0.07)$ & $0.040(0.19)$ \\
\hline school enrolment & $\begin{array}{c}0.018^{* * * *} \\
(0.00)\end{array}$ & $0.005(0.48)$ & $-0.001(0.91)$ & $0.000(0.95)$ & $0.010(0.16)$ \\
\hline obs. & 515 & 481 & 519 & 500 & 491 \\
\hline reform obs. & 159 & 155 & 207 & 163 & 99 \\
\hline R2 (Mc Fadden) & 0.12 & 0.13 & 0.10 & 0.13 & 0.16 \\
\hline
\end{tabular}

p values in parentheses, */**/***: significant at 10\%/5\%/1\%. 
Similar to the reform need proxies the variables representing rational reform resistance perform worse in these differentiated regressions: life expectation and age structure are always insignificant with one exception in the stable money regression.

The contrary holds for the proxy for the extent of rational ignorance and limited irrationality: School enrolment is now strongly significant with the expected sign in the reform regression for the size of government: Countries with better educated citizens are more likely to reform the government sector and to cut back government spending and taxes.

\section{Conclusions}

There is no one-dimensional answer why countries have different inclinations to delay or even refuse growth inducing reforms. Traditional answers given in the economic literature are related to the extent of economic crisis or to politicaleconomic factors. Our theoretical considerations suggest that these traditional answers are possibly incomplete. Limited rationality on the side of voters might be a further factor in the explanation of reform deadlocks: Blockades might occur because it is individually costless not to judge reforms in a completely rational way.

Our empirical approach is not guided by the ambition to explore the full universe of rational and irrational determinants of reforms. However, we try to shed light on the weight of three classes of factors: those related to the objective need for reforms, those representing political-economic reform-resisting forces and those associated with rational ignorance or limited rationality.

Not surprisingly, there is strong evidence that the objective need for reforms is highly relevant: The worse a country's initial institutional setting the more likely are reforms. Equally, a poor growth performance has a positive impact on a country's ability to overcome reform resistance.

Among political-economic proxies the age structure has a certain explanatory power at least in the regressions based on the EFW total indicator. Here, reform probabilities decrease with the age of a population. This is a worrying result given the demographic future of industrial countries and the resulting needs for reforming the social systems.

Data availability does not allow to test for the relevance of limited information and limited rationality in an extensive way. School enrolment as the related proxy is significant only in the government reform regression. This means a higher level of education makes it easier to reform the government sector. This is a plausible result: E.g. cutting back government subsidies is associated with immediate and highly visible losses whereas the benefits (future tax cuts, growth) are more abstract. A higher level of education may make it easier to welcome this kind of institutional change. 
Apart from these results, other interesting insights emerge as a by-product: The significant period dummies are evidence for changing fashions in the focus of reforms. Deregulation, for example, only became a trend in the first half of the nineties.

Obviously, this empirical approach is just a first step and much more needs to be done to really understand the economics of reforms. Apart from macro-approaches as applied in this paper micro-approaches e.g. on the basis of experimental research seem to be necessary. Differencing for example between by poor information and limited rationality as causes for the rejection of beneficial reforms is hardly possible on the basis of macro data. In this sense a frequent final conclusion applies particular well to this paper: More research is needed on the empirics of reforms.

\section{References}

Alesina, Alberto and Allan Drazen (1991): Why Are Stabilizations Delayed?, American Economic Review, 81 (5), 1170-1188.

Caplan (2001a): Rational Irrationality and the Microfoundations of Political Failure, Public Choice, 107 (3/4), 311-331.

Caplan, Bryan (2001b): Rational Ignorance versus Rational Irrationality, Kyklos, 54 (1), 3-26.

Daniel, Kent, Hirshleifer, David and Siew Hong Teoh (2002): Investor Psychology in Capital Markets: Evidence and Policy Implications, Journal of Monetary Economics, 49 (1), 139-209.

De Haan, Jakob (2003): Economic Freedom: Editor's Introduction, European Journal of Political Economy, 19, 395-4003.

Downs, Anthony (1957): An Economic Theory of Democracy, New York: Harper.

Fernandez, Raquel and Dani Rodrik (1991): Resistance to Reform: Status Quo Bias in the Presence of Individual-Specific Uncertainty, American Economic Review, 81 (5), 1146-1155.

Gwartney, James and Robert Lawson (2003a): The Concept and Measurement of Economic Freedom, European Journal of Political Economy, 19, 405-430.

Gwartney, James and Robert Lawson (2003b): Economic Freedom of the World, 2003 Annual Report, Fraser Institute, Vancouver.

Heinemann, Friedrich (2001): Die Psychologie begrenzt rationaler Wirtschaftspolitik: Das Beispiel des Reformstaus, Zeitschrift für Wirtschaftspolitik, 50,1, 96-110. 
Kahneman, Daniel, Knetsch, Jack L. and Richard H. Thaler (1991): Anomalies, the Endowment Effect, Loss Aversion and Status Quo Bias, Journal of Economic Perspectives, 5 (1), 193-206.

O’Driscoll Jr., Gerald P., Feulner, Edwin J. and Mary Anastasia O’Grady (2003): 2003 Index of Economic Freedom, Heritage Foundation, Washington, DC.

Pitlik, Hans and Steffen Wirth (2003): Do Crises Promote the Extent of Economic Liberalization?: an Empirical Test, European Journal of Political Economy, 19, 565-581.

Rodrik, Dani (1996): Understanding Economic Policy Reform, Journal of Economic Literature, 34 (March), 9-41.

Samuelson, William and Richard Zechkauser (1988): Status Quo Bias in Decision Making, Journal of Risk and Uncertainty, 1, 7-59.

Tversky, Amos and Daniel Kahneman (1991): Loss Aversion in Riskless Choice: A Reference-Dependent Model, The Quarterly Journal of Economics, 106 (4), 1039-1061.

Wittman, Donald (1995): The Myth of Democratic Failure: Why Political Institutions are Efficient. Chicago: University of Chicago Press. 


\section{Appendix: List of variables}

\begin{tabular}{|c|c|c|}
\hline variable & Calculation & source \\
\hline growth & $\begin{array}{l}\text { average annual real GDP growth in five-year- } \\
\text { period prior to five-year-window }\end{array}$ & WDI \\
\hline change growth & $\begin{array}{l}\text { difference average growth between two five- } \\
\text { year-periods prior to five-year-window }\end{array}$ & WDI \\
\hline GDP p.c. (PPS) & $\begin{array}{l}\text { GDP p.c. in PPS (current international \$), in } \\
\text { the first year of five-year-window }\end{array}$ & WDI \\
\hline change in GDP p.c. (PPS) & $\begin{array}{l}\text { change in GDP p.c. (PPS) during five-year- } \\
\text { period prior to five-year-window }\end{array}$ & WDI \\
\hline unemployment rate & $\begin{array}{l}\text { unemployment rate at first year of five-year- } \\
\text { window }\end{array}$ & WDI \\
\hline change unemployment rate & $\begin{array}{l}\text { five year change in unemployment rate prior } \\
\text { to five-year-window }\end{array}$ & WDI \\
\hline export-GDP-ratio & $\begin{array}{c}\text { exports in \% GDP, in the first year of five- } \\
\text { year-window }\end{array}$ & WDI \\
\hline capital flows & $\begin{array}{l}\text { private capital flows (in- and outwards) in \% } \\
\text { GDP, first year of five-year-window }\end{array}$ & WDI \\
\hline $\begin{array}{l}\text { change real effective } \\
\text { exchange rate }\end{array}$ & $\begin{array}{l}\text { change real effective exchange rate within } \\
\text { five-year-period prior to five-year-window } \\
\text { (decline stands for depreciation) }\end{array}$ & WDI \\
\hline population & $\begin{array}{l}\text { total population at first year of five-year- } \\
\text { window }\end{array}$ & WDI \\
\hline population share $>=65$ & $\begin{array}{l}\text { population } 65 \text { and above in } \% \text { of total } \\
\text { population at first year of five-year-window }\end{array}$ & WDI \\
\hline dependency ratio & $\begin{array}{c}\text { age dependency ratio (dependents to working } \\
\text { age population) at first year of five-year- } \\
\text { window }\end{array}$ & WDI \\
\hline life expectation & $\begin{array}{c}\text { life expectation at birth at first year of five- } \\
\text { year-window }\end{array}$ & WDI \\
\hline credit & $\begin{array}{c}\text { domestic credit provided by the banking } \\
\text { sector, in \% GDP, first year of five-year- } \\
\text { windwo }\end{array}$ & WDI \\
\hline school enrolment & $\begin{array}{l}\text { school enrolment, tertiary (\% of age group), } \\
\text { in the first year of 5-year-window }\end{array}$ & WDI \\
\hline $\begin{array}{l}\text { daily newspapers per } 1,000 \\
\text { people }\end{array}$ & first year of five-year-window & WDI \\
\hline TV sets per 1,000 people & first year of five-year-window & WDI \\
\hline
\end{tabular}

WDI: World Bank World Development IndicatorsEinführung. 